\title{
The Implementation of Multicultural Based Learning in Reducing Intolerance Attitudes among Students
}

\author{
Munawwir Hadiwijaya \\ IKIP Budi Utomo \\ $\underline{\text { mr.awinwijaya@gmail.com }}$ \\ Adi \\ IKIP Budi Utomo \\ adidoang@gmail.com
}

Received: July 30, 2018

Accepted: August 17, 2018

Url: http://dx.doi.org/10.30587/jetlal.v2i2.623

Published: August 31, 2018

doi: $10.30587 /$ jetlal.v2i2.623

\begin{abstract}
The purpose of this study is to determine the effectiveness of multicultural based learning with Multiple Perspectives Approach in suppressing intolerance among students. The result shows that there is a significant influence of multicultural learning models with multiple perspective approaches to students' tolerance levels: 4.56 (control) and 6.28 (experimental). The tolerance level of students after applying multicultural based learning methods with multiple perspective approaches is better $\left(X_{-} \mathrm{A} 1 \mathrm{n}=6.76\right)$ compared to the tolerance level of students using conventional learning methods ( $\mathrm{X} \_\mathrm{A} 2=4.11$ ). The students' four values emphasized on the implementation of multicultural based learning methods are increased.
\end{abstract}

Keywords: Multiculturalism, Intolerance, Multicultural Based Learning

\section{Introduction}

Intolerance among students in Malang has reached an alarming level. The diversity of students studying in this city makes Malang as one of the City with the largest multicultural society in Indonesia. Frequent intertribal student fights in this City is evidence that our students have a low level of awareness about diversity. As recently (October 2016) occurred, a case of fighting between Ambonese students group, Maluku and Sumba student group, NTT, which killed one Ambon student. Not limited to ethnicity, but religion and race are also often sources of noise among students. The estrangement of all these events is the lack of awareness of tolerance among them.

In a multicultural society, tolerance is very important, both in speech and in behavior. In this case, tolerance means respecting and learning from others, respecting differences, bridging cultural gaps, so as to attain common attitudes. Tolerance is also the beginning of accepting that difference is not a wrong thing, rather the difference must be respected and understood as wealth. Tolerance is also the basis to create a peaceful and harmonious life.

Based on the above situation, 'Multicultural-Based Education' becomes very important in this context. Banks (1993) defines multicultural education as education for people of color. Multicultural education wants to explore differences as a necessity (God's grace), in which with that condition, people are able to accept the difference with full sense of tolerance. As a nation with diverse communities such as religion, ethnicity, race, culture, customs, language, and so on make the people of Indonesia as a pluralistic society. In this diverse interaction, it is a challenge to unite the Indonesian nation into a force that can uphold the diversity and pluralistic of its people. 
According to Banks (1993) the goals of multicultural-based education can be identified into four categories: 1) To enable the role of campus in viewing of the presence of diverse students; 2) To assist students in establishing positive treatment of cultural, racial, ethnic, and denominational differences; 3) To provide students resilience by teaching them in decisions making and social skills; and 4) To assist students in building crosscultural dependence and to give them a positive picture of group differences.

One of the approaches in multicultural-based learning is the Multiple Perspectives Approach, it focuses on a single issue discussed from different perspectives of different groups. A Multiple perspective approach helps students to realize that a common event is often interpreted differently by others, where the interpretation is often based on the group values they follow. Solutions that are considered good by a group (because they fit their values) are often not considered good by other groups because they do not match the values they follow (Savage \& Armstrong, 1996). The main purpose of this study is to measure the effectiveness of multicultural-based learning with Multiple Perspectives Approach in reducing intolerance attitudes among students.

With the application of multicultural-based learning in IKIP Budi Utomo Malang is expected to increase the sensitivity, awareness, and tolerance among students of multiculturalism that exists.

Therefore, the purpose of this study is to determine the effectiveness of multicultural based learning with Multiple Perspectives Approach in reducing intolerance among students.

\section{Review of Related Literature Multiculturalism}

"Multiculturalism" is essentially a worldview which can then be translated into cultural policies that emphasize acceptance of the religious, plurality, and multicultural realities that exist in the life of society. Multiculturalism can also be understood as a worldview which is then manifested in political consciousness (Azra, 2007). Multiculturalism includes an understanding, appreciation and assessment of one's culture, as well as a respect and curiosity about other's ethnic culture (Blum, cited Lubis, 2006: 174). Multiculturalism includes ideas, views, policies, attitudes and actions, by a nation's people, ethnically, culturally, religiously and so on, but has the aspiration to develop the same spirit of nationalism and has pride in maintaining the pluralism (Harahap , 2007 , citing Muzhar).

\section{Tolerance}

Tolerance is an attitude of mutual respect between groups or between individuals in society. Tolerance prevents discrimination even though there are many different groups or groups within a community group. Examples of tolerance in general include: respecting the opinions and/ or thoughts of others who are different and help each other for humanity regardless of race/ race/ religion/ belief. In society, the growth of tolerance leads to peaceful living side by side and avoid hostilities.

\section{Multicultural Based Learning}

Multicultural education to date has not been defined by default. However, there are some opinions of experts on multicultural education. Among them are Andersen and Cusher (1994: 320) interpreting multicultural education as education about cultural diversity. Multicultural education is an education that encompasses all students regardless of their groups, such as gender, ethnicity, race, culture, social strata, and religion.

Bank (1993) explains, that multicultural education has several dimensions that are interconnected with one another, namely:

1. Content Integration, which integrates various cultures and groups to illustrate basic concepts, generalizations, and theories in subjects/ disciplines. 
2. The knowledge construction process, which brings students to understand the cultural implications into a subject.

3. An equity pedagogy, which adjusts teaching methods by means of student learning in order to facilitate students' academic achievement in a variety of racial, cultural, or social.

4. Prejudice reduction, which identifies racial characteristics of students and determines their teaching methods. Then, train groups to participate in sports activities, interact with all different ethnic and racial staff and students in an effort to create a tolerant and inclusive academic culture.

While the approach that can be used in the process of learning in the multicultural class according to Bannet and Spalding (1992) is a single group study approach and multiple perspective approach:

a. Single group studies approach

This approach is designed to assist students in studying the views of particular groups in more depth. Therefore, there should be data about the group's history, customs, clothing, houses, food, religious beliefs, and other traditions. Data about the group's contributions to the development of music, literature, science, politics and others must be confronted with the students. This approach focuses on issues that are full of group values under review.

b. Multiple perspective approach

It focuses to a single issue discussed from different perspectives of different groups. In general, teachers have multiple perspectives in their learning. In this regard, Bannet and Spalding (1992) suggest that learning uses a multiple perspective approach, with argumentation that the approach appears to be more effective. A multiple perspective approach helps students to realize that a common event is often interpreted differently by others, where the interpretation is often based on the group values they follow. Solutions that are considered good by a group (because they fit their values) are often not considered good by other groups because they do not match the values they follow (Savage \& Armstrong, 1996).

The advantage of this multiple perspective approach lies in the process of thinking critically on the issues being discussed so as to encourage students to eliminate prejudice. Interaction with the views of different groups allows students to empathize. Students who have a great sense of empathy make it possible to respect their differences of perspective. Of course it will be able to reduce prejudice against other groups.

The choice of strategies used in developing multicultural learning based on, among others: Cooperative Learning strategy combined with Concept Attainment strategy, Value Analysis, and Social Investigation strategy.

\section{Previous Research}

Similar research has been conducted by Farida Hanum and Sisca Rahmadonna, 2010, attempting to embrace multicultural learning at the elementary level, entitled "Implementation of Multicultural Learning Models at Elementary Schools of Yogyakarta Special Province". From this research can be seen that the level of understanding of primary school students about diversity increased significantly without overriding the essence of the topics of discussion.

Nurul Zuriah, 2011, entitled Model Development of Multicultural Education of Multicultural Based Local Wisdom in Post-Reform Physical Social Phenomenon in Higher Education. The result of the experiment showed that the increase of the learning product resulted in the improvement of multicultural competence among students with the $\mathrm{F}$ value of 4.585 which has a significance less than 0.05 . the results of these studies show substantially that these results show that MBKL Civics is effective for improving students' multicultural competencies. 
In 2012, Tri Kurnia Wardani, conducted a research entitled "The Use of Comic Media In Sociological Learning On The Topics Of Multicultural Society". The results showed that Students were actively responding to what they discussed. When group discussions take place, students look active. Group one responds to another group. From these data, means that the comics applied can support student learning activities.

\section{Research Method}

\section{Research Design}

The design of research to be used in this study is the type of quantitative research with experimental research as the design, research conducted to determine the effect of the treatment that has been given by researchers deliberately against a symptom that has been determined under the control conditions of variables, or with other words as a way to investigate whether an observed phenomenon is affected by the presence of certain conditions.

The experimental procedure intends to compare the effects of the independent variables on the dependent variable through manipulation or control over the independent variables. The experimental design used in this study is the Quasi design experiment "Pretest-Posttest - Only Control Group".

\section{Population and Sample}

Sugiyono (1997) provides an understanding that the population is an area of generalization that consists of objects or subjects that become a certain quantity and characteristics determined by researchers to be studied and then drawn conclusions. The population is the whole subject of the study which in this case is the English Language Department student of the IKIP Budi Utomo Malang.

The sample represents a portion of the population being targeted by actual research or subjects being the source of actual data (Poerwati, 2000). According to Arikunto (1992) the sample is part of the population or representatives that can represent the characteristics of the population to be studied. The sample in this study is the second semester students of 2017 Department of English Language Education IKIP Budi Utomo Malang. The study took samples of 2 classes. This is in accordance with the minimal needs of this study.

\section{Research Setting}

This research is conducted at IKIP Budi Utomo Malang, Jalan Citandui 04 Malang. Research will be conducted during the lesson time is ongoing and done on the campus effective day. This research will be carried out precisely in March 2018 in three subjects, namely: Speaking II, Reading II, and Introduction to Linguistics with the use of time for each method and course that is 4 x 50 minutes which means the total overall application of treatment is 600 minutes.

\section{Data Collection Method}

In this research data collection method used is multiple choice test using 48 questions psychological test technique, the Bias Racial Test adopted from the IAT (Implicit Association Test) which is the data used to find information related to the level student tolerance (pre-test and post-test). In addition, this study also uses interviews and observations for both lecturers and students whose results are used as supporting data in making conclusions in this study.

\section{Validity and Reliability}

The validity used is content validity which is related to the ability of the assessment tool in measuring the content that should be. This means that the test is able to reveal the contents of a concept or variable to be measured. 
The reliability of the assessment tool is the determination or constancy of the tool in assessing what is judged. That is, whenever the assessment tool is used will give relatively the same results. In this case the researcher will use split-half method which then uses Brown's Sepearment to determine the correlation coefficient for all the questions with the formula:

$$
r_{x x}=\frac{2 r \frac{1}{2} \frac{1}{2}}{1+r \frac{1}{2} \frac{1}{2}}
$$

Explanation:

$$
\begin{aligned}
& \mathrm{r}_{\mathrm{Xx}} \quad \text { : Overall reliability coefficient. } \\
& \mathrm{R} \frac{1}{2} \frac{1}{2} \text { : Correlation (r) of two splits. }
\end{aligned}
$$

\section{Data Analysis Method}

Data analysis method that will be used in this research is t-test technique with the following formula:

$$
t-\text { test }=\frac{\bar{X}_{1}-\bar{X}_{2}}{\sqrt{\left[\frac{S D_{1}^{2}}{N_{1}-1}\right]+\left[\frac{S D_{2}^{2}}{N_{2}-1}\right]}}
$$

\section{Finding and Discussion}

\section{Findings}

\section{Description of Pretest Data Group Experiment and Control}

From the pretest result conducted on 07 March 2018, in the students of English Education Department IKIP Budi Utomo Malang Force 2016, using Bias Racial Tests adopted from IAT (Implicit Association Test) developed by Harvard University to measure one's tolerance level, by comparing two large ethnic in Indonesia, namely: Java and East Indonesia found that the mean between the two groups respectively is 4,21 and 4,34, with the lowest, medium, and highest values, respectively, 1,32 and 6,34. 
The results of the analysis of pre-test data descriptions of the experimental group showed that of the 15 sample of students in the experimental group were as follows 3 high categorized students, 10 moderate, and the rest were low.

This condition is not much different from the pretest results in 15 sample students in the control group, the group in which the study only used conventional methods, for medium and low categories respectively as follows, 4, 9, and 2. For more details can be seen on table below:

Table 1 Recapitulation of Pretest Results of Experimental and Control Groups

\begin{tabular}{lcccccc}
\hline \multirow{2}{*}{ Category } & \multicolumn{3}{c}{ Experiment } & \multicolumn{3}{c}{ Control } \\
& Interval & $\mathbf{N}$ & $\mathbf{\%}$ & Interval & $\mathbf{N}$ & $\boldsymbol{\%}$ \\
\hline High & $6 \geq 7$ & 3 & 20 & $6 \geq 7$ & 4 & 26,67 \\
Medium & $4 \geq 5$ & 10 & 66,67 & $4 \geq 5$ & 9 & 60 \\
Low & $3<0$ & 2 & 13,33 & $3<0$ & 2 & 13,33 \\
Amount & & $\mathbf{1 5}$ & $\mathbf{1 0 0}$ & & $\mathbf{1 5}$ & $\mathbf{1 0 0}$ \\
\hline
\end{tabular}

The table shows that between the experimental and control groups each have a tolerance level that is not too high with only $20 \%$ and $26.67 \%$ respectively measured by using Bias Racial Tests. While the remaining are categorized into medium with $66.67 \%$ and $60 \%$ respectively, and the rest are low. It indicates that there are still many students who do not yet have a sense of tolerance for differences that becomes the basis for the creation of a tolerant and peaceful society. This result also shows that prejudice against skin color and race is still quite high among students who give a certain stigma to a particular ethnicity.

\section{Post-Test Data Description Experiment and Control Group}

Below is the result of post-test assessment that has been done on the experimental group and the control group. Indicators of expected change of attitude variables consist of: the increase of understanding of the concept of multiculturalism, tolerance that is shown by changes in the way of view of certain ethnic, the disappearance of stigma over certain ethnic, the increase of ability to suppress the feeling of excessive primordialism in each individual.

Indicators are formulated and arranged in the form of test questions. In the post-test, the model used still uses the Bias Racial Test. What distinguishes between items that exist in the pre test and post test is the comparison variable. The previous pre test compares only Javanese and Eastern Indonesian tribes with pleasant and unpleasant adjectives words to represent the pictures by selecting the numbers that best fit the feelings of the testers, with number 1 as the "least appropriate" marker and the number 7 indicates "most appropriate". In the post test, the ethnicities compared are four major ethnic groups in Indonesia, those are: Java, Kalimantan, Eastern Indonesia, and Madura, all of which are in IKIP Budi Utomo Malang campus. Below is a table of post test results conducted on 04 June 2018.

Table 2 Recapitulation of Pretest Results of Experimental and Control Groups

\begin{tabular}{lcccccc}
\hline \multirow{2}{*}{ Category } & \multicolumn{3}{c}{ Experiment } & \multicolumn{3}{c}{ Control } \\
& Interval & $\mathbf{N}$ & $\boldsymbol{\%}$ & Interval & $\mathbf{N}$ & $\boldsymbol{\%}$ \\
\hline High & $6 \geq 7$ & 10 & 66,67 & $6 \geq 7$ & 3 & 20 \\
Medium & $4 \geq 5$ & 5 & 33,33 & $4 \geq 5$ & 9 & 60 \\
Low & $3<0$ & 0 & 0 & $3<0$ & 3 & 20 \\
Amount & & $\mathbf{1 5}$ & $\mathbf{1 0 0}$ & & $\mathbf{1 5}$ & $\mathbf{1 0 0}$ \\
\hline
\end{tabular}


From the table above, it can be seen that there is a significant change quantitatively between students who joined in the experimental group after being applied multicultural-based learning model for 600 minutes from 10 April 2018 to 19 Mei 2018, with students who joined in a control group that only uses conventional methods in its teaching, in terms of tolerance level. The average experimental group increased $60 \%$ to high category. While the students who are in the control group did not experience significant changes from the previous pretest results.

\section{Data Analysis Results}

To test the hypothesis and to know the effectiveness of multicultural-based learning compared to conventional method given to the students seen from the difference of their tolerance level based on Bias Racial Test result, the calculations statistic with t-test formula applied to the computer, which can be seen in the table below:

Table 3 Summary between Groups

\begin{tabular}{lrccc}
\hline \multicolumn{2}{c}{ Varian Source } & T Value & P & Explanation \\
\hline Multicultural & based & 2.983 & 0.004 & Significance \\
learning methods $\quad$ with & & & \\
multiple & perspective & & & \\
approaches & (A1) & & & \\
Compared & to & & \\
Conventional $\quad$ Learning & & & \\
Methods (A2) & & & & \\
\hline
\end{tabular}

Based on the results of the analysis, there is a very significant difference $(t=2.983, p=0.004)$ on the level of students' tolerance using multicultural-based learning compared to tolerance of students using conventional learning method. Students' tolerance level after applied Multicultural based learning has better result $\left(\mathrm{X} \_\mathrm{A} 1 \mathrm{n}=6.76\right)$ than student tolerance level using Conventional Learning method $\left(\mathrm{X} \_\mathrm{A} 2=4.11\right)$.

\section{Discussion}

Based on the results of the above analysis it is known that there is a significant difference between the level of tolerance of students in the classroom that uses multicultural-based learning and conventional methods. The differences obtained by the students are influenced by several factors, both internal and external factors.

There are four emphases on the implementation of multicultural based learning in this study; namely: a) multiculturalism, b) diversity, c) pluralism, and d) relativism.

First the value of multiculturalism, can simply be interpreted as the ability to accept and tolerate differences. Muzhar (in Harahap, 2007) states that multiculturalism is an idea that is built on the basis of the perspective of differences and prioritizes togetherness. Multiculturalism is an idea of willingness to coexist peacefully with people and other groups. An idea that was born from a global discourse on pluralism and harmony, diversity in peace and harmony, as well as a sharp criticism for those who are still discriminatory towards marginal, minority, poor and women groups. In multicultural societies, the issue of differing views often creates its own problems between members of the community, this is due to a lack of ability to adapt and tolerate the existing differences.

The characteristic of a multicultural society is tolerant. They live in a spirit of peaceful co-existence, living side by side peacefully. Every social and cultural entity always carries its identity, does not fuse and then disappears, but also not shown as pride that exceeds the appreciation of other entities. In the perspective of multiculturalism, both individuals and groups from various ethnicities and cultures, live in an atmosphere of dynamic social cohesion without losing their ethnic and cultural identity. Although they live united in the social realm, but between entities there remains a distance. 
By focusing on integrating material with multicultural values, the views of students from different ethnicities about differences can be directed toward a positive point. This is evidenced by post test results that indicate a decrease of negative prejudices against certain ethnicities. The results of observations made during the lesson were carried out indicates a change of attitude experienced by the students in experimental class. If previously the students just hang out with friends who come from the same ethnic, gradually they can mingle with friends of different ethnicity. While the results of interviews conducted on some students and lecturers, if before this learning method is implemented, the students still look at someone based on tribe and ethnicity, it is slightly reduced after implementation.

Second, the value of diversity, in this study is defined as the ability to perceive differences as strengths. Suparlan (1999), from the view of sociology, interpretes it as a cultural richness that is seen as a way that exist in a culture of a group or society to express their expression. Growing this capability in each individual is not easy, if the first challenge was limited to the defense and implementation of the values of rigid regional primordialism, it is now harder with the occurrence of apathetical sense to the surrounding environment. This apathetic is strongly influenced by the lifestyles of modern society that tend to be individual which arise due to the development of technology, especially smartphone. This condition also occurs in the interaction between students in IKIP Budi Utomo Malang.

A society (including a people nation like Indonesia) has a common culture whose features are like a mosaic. Smaller societies form a larger society by its cultures. This mosaic analogy is attempted to build on the students in this research by providing material about the diversity of Indonesian culture, which can be a very big strength if it can be managed properly. Cultural knowledge that contains symbols of knowledge used by the community member to understand and interpret the environment. The cultural knowledge will be in the form of cultural values of ethnic and cultural values of Indonesia, in which contains local wisdom of local culture and local tribes.

Preliminary observations and interviews about students' attitudes in viewing differences as strengths are found to be very weak. They tend to see difference as something to be avoided and suspected, therefore they prefer to associate with the same, especially tribe and ethnic groups. However, after the implementation of multiculturalbased learning, conducted in three different courses namely speaking II, Reading II, and Introduction to Linguistics, the understanding of the value of diversity slowly began to be embedded in students. This is evidenced by the level of solidarity in the team that is getting better in solving problems given by the lecturer.

Third, pluralism, in this study is defined as the ability to regard differences as a shared experience. In social science, according to Osman (2006) the meaning of pluralism is the acceptance of diversity so that every human being has rights and obligations that are equal to other human beings. Whereas Imarah (1999) states that pluralism is based on virtue (uniqueness) and peculiarities. The concept of plurality presupposes the existence of things that are more than one, diversity indicates it as something different, heterogeneous, and even unequal. Plurality is a common social phenomenon encountered in every life of society, nation and state. Indonesia, as an archipelagic country, has since become a multi-racial, multi-ethnic, multi-religious, and multi-cultural nation. The plurality of Indonesian society can be seen both horizontally and vertically. Horizontally, Indonesians can be grouped according to religion, race, ethnicity, culture, and locality. Vertically, the people of Indonesia can be divided into upper classes, middle class, and lower class.

Pluralism reflected in the Budi Utomo IKIP students, which is a miniature of the broad description above, becomes an important thing that must be maintained in harmony. Plurality patterns on this campus have been formed for a long time, where there are many ethnicities, tribes, and religions that study at this campus. However, understanding and awareness about pluralism itself is not maximally known and applied by students. Real examples of this assumption are individual attitudes that are still very high and also still compartmentalized with primordial regionalism as the limit, this is based on observations and interviews conducted before the application of multicultural based learning. They are more comfortable with 'their own groups' when they have to solve a problem rather than having to be with 'other group' students, even though they actually realize if they alone will 
still need 'other groups' to perfect the work. But there is a sense of pride or inferior if they have to 'ask for help' to groups outside of them, this attitude is the main obstacle for students to have better at understanding something. Instead of complementing each other, they tend to maintain this attitude.

Furthermore, the experiment carried out by classifying students based on ethnicity and religion, by 'stripping' the shortcomings of each group at first, to raise awareness that they still needed other groups to cover up the shortcomings. The concept of pluralism as a force gradually begins to be embedded in collective problem solving attitudes. Then they are grouped heterogeneously by mixing each element in a group, here begins to reflect the collective understanding manifested in group collaboration when they are faced a problem.

Fourth, relativism, in this study is defined as the ability to see things from the perspective of others. Relatifivism in this study is closely related to cultural relativism, there is no community that has the right to claim its culture is superior to others. Abdala (in Nurulaen 2012) states, cultural relativism is the understanding that all cultures are good, there is no culture that is considered superior while others are inferior. Culture is the result of social construction. Culture does not contain certain essences that make it "good" or "bad". It is possible that a cultural behavior is considered good in a particular community, but on the contrary it is considered strange or even funny by other communities. So, even if there might be cultural excellence, it is only limited to excelling in the context of the community, not because it is compared to other cultures.

To get to that cultural relativism, every person from a different culture must be able to empathize, putting himself in the atmosphere of a particular ethnic culture that is different from his, to be able to discard the negativesubjective-ethnocentrism view of another tribe. Understanding cultural and religious values that are contrary to the cultural and religious values adopted is imperative. Empathy is one of the emphases in this study, trying to feel what others feel must be embedded in multicultural students.

Learning is done to foster a sense of empathy for students, namely by emphasizing the similarities that exist within themselves, with the theme 'we are brothers'. Students are invited to watch war-themed videos, whether ethnic or religious. From here they are assigned in heterogeneous groups to analyze the impacts of war, trying to feel and ponder if they are in a position like the one in the video. Almost all students think that war is a bad thing. After awakening of sympathy, students are invited to dive into each other, then reflect on their heterogeneous friends to find common ground between them, whether tribal, ethnic, religious, national, or divine. With the concept of equality and togetherness taught in class, gradually the awareness of relativism can be embedded in students.

\section{Conclusions}

In line with the results of the research analysis described above, then as the research findings can be concluded that:

1. There is a significant influence of multicultural learning models with multiple perspective approaches to students' tolerance levels, this is based on a comparison of the results of racial bias tests adopted from the IAT (Implicit Association Test) developed by Harvard University to measure a person's tolerance level, by comparing four major ethnic groups in Indonesia, namely: Java, Kalimantan, Eastern Indonesia, and Madura, all of which are in the IKIP Budi Utomo campus in Malang. The control class has an average of 4.56, while the experimental class has an average of 6.28 , meaning that the average experimental class is greater than the control class with a high predicate.

2. The tolerance level of students after applying multicultural based learning methods with multiple perspective approaches is better $\left(X_{-}\right.$Aln $\left.=6.76\right)$ compared to the tolerance level of students using conventional learning methods $\left(X \_A 2=4.11\right)$.

3. There are four values emphasis on the implementation of multicultural based learning methods in this study; namely: a) multiculturalism, b) diversity, c) pluralism, and d) relativism; based on the results of 
posttest, observation, and interview, it can be concluded that awareness to the importance of these four values in students of experimental class increased.

\section{References}

Andersen, R. dan Cusher, K. (1994). Multicultural and intercultural studies, dalam Teaching Studies of Society and Environment (ed. Marsh,C.). Sydney: Prentice-Hall.

Arikunto, S. 1996. Prosedur Penelitian Suatu Pendekatan Praktek. Rineka Cipta. Jakarta.

Ary, D. 2002. Introduction to Research in Education. United States: Wadsworth.

Azra, A. 2007. -Identitas dan Krisis Budaya: Membangun Multikulturalisme Indonesia. http://www.kongresbud.budpar.go.id/58\%20ayyumardi\%20azra.htm. Assessed on 22 June 2017

Banks, J. 1993. Multicultural education: historical development, dimensions, and practice. Review of Research in Education, 19: 3-49.

Bennett, C. \& Spalding,E. 1992. Teaching the Social Studies: Multiple Approaches for Multiple Perspectives. In Theory and Research in Social Education. XX:3(263-292).

Depdiknas, Http:www.depdiknas.go.id/selayangpandangpenyelenggaraanpendidikannasional. “Assessed on 22 June 2017”.

Harahap \& Rifai, A. 2007. Multiculturalism. Wikipedia. “Assessed on 22 June 2017”.

Imarah, M. 1999. Islam dan Pluralitas: Perbedaan dan Kemajemukan dalam Bingkai Persatuan, Jakarta: Gema Insani Press.

Kerlinger, F. N. (1973). Founding Of Behavior Research. Holt. Rinchart and Winston Inc. New York.

Lubis, A. Y. 2006. Dekonstruksi Epistemologi Modern. Jakarta: Pustaka Indonesia Satu.

Maidiyah, A.1999. Pendekatan, Metode, dan Strategi dalam Pengajaran. Surabaya: Airlangga University Press.

Nurulaen, Y. 2012. Relativisme Budaya Bagi Masyarakat Multikultural Indonesia. Jurnal Studi Agama dan Masyarakat Vol.6, No. 2, Desember 2012

Savage \& Armstrong, 1996).Effective Teaching in Elementary Social Studies.Virginia: Merrill.

Sugiyono. (1999). Metode Penelitian Administrasi. Bandung: CV. Alfabeta.

Suparlan, P. 1999. Orang Sakai di Riau, Masyarakat Terasing Dalam Masyarakat Indonesia. Jakarta; Yayasan Obor 